\title{
Surface Deformation Monitoring Using Time-lapse Microgravity Method in Central and East Lombok Regencies
}

\author{
Suhayat Minardi ${ }^{1 *}$, Teguh Ardianto ${ }^{1}$, Alfina Taurida Alaydrus ${ }^{1}$ \\ ${ }^{I}$ Department of Physics, Faculty of Mathematics and Natural Sciences, University of Mataram, Jl. Majapahit no. 62 \\ Mataram, Mataram, 83125, Indonesia
}

( Received: December 6, 2019, Revised: February 28, 2020, Accepted: August 19, 2020 )

\begin{abstract}
Surface deformation is a natural occurrence on the surface of the earth. The deformation can be in the form of subsidence or uplifting of the land surface. In this research, an time-lapse microgravity method will be applied to monitor surface deformation that occurs in Central Lombok and East Lombok Districts. The method of time-lapse microgravity is repetitive gravity measurement at the same point with a certain time interval, the measured magnitude is a change in the value of the acceleration of gravity and the microGal scale. Measurements were made in August 2016, April 2018, and June 2019. The measured value of the change in gravitational acceleration is the superposition of the changes caused by subsurface and surface sources. Separation of the two values is carried out using striping filter, which takes into account the ratio of density, thickness, and depth of the surface and subsurface layers. Land subsidence occurred during the period August 2016 to April 2018 and land uplifting occurred during the April 2018 to June 2019 period. This land subsidence occurred due to natural compacting and minor tectonic activity (small earthquakes that were not felt) while land uplifting was occurred due to major tectonic activities, in the form of the Lombok Earthquake in July to September 2018.
\end{abstract}

Keywords: deformation, Lombok Earthquake, natural compacting, stripping filter, tectonic activity

\section{INTRODUCTION}

Bali and the surrounding area is one area with a high level of seismic activity in Indonesia. IndoAustralian plate subduction of Eurasian plates at a rate of $7 \mathrm{~cm}$ per year has resulted in the effect of geological structures of active faults in the Bali and surrounding areas $[1,2]$. Based on this tectonic condition, seismic activity in Bali is strongly influenced by two earthquake generators, namely plate subduction activity and local fault activity [3].

In the subduction zone due to continental plates being pushed by oceanic plates causing continental plates to move upward causing a negative anomaly response and vice versa. While volcanic earthquakes caused by rising magma near the surface will cause deformation of the surface of the mountain that can cause time-lapse microgravity responses can be negative or positive depending on the magnitude of the increase in magma and the size of the deformation that occurs on the surface. Because of different earthquakes mechanisms, will make a different in time-lapse micogravavity respond.

Fault activity on Lombok Island has been detected based on research [4].

Of the two measurements, the elevation contours of the GPS measurements in 2016 and 2018 did not coincide, as shown in Figure 1. This shows the surface deformation in the vertical direction in the study area. In addition to vertical deformation, deformation in the horizontal direction also occurs, as shown in Figure 2.

Given the fact that fault activity triggers an earthquake, then the earthquake gives a negative effect of the disaster, one of which is the occurrence of deformation on the surface of the earth in the form of subsidence or removal. So this study aims to monitor this phenomenon during the intervals of 2016 to 2019 by using the time-lapse microgravity method.

\footnotetext{
* Corresponding author

E-mail address: suhayat.minardi@unram.ac.id
} 


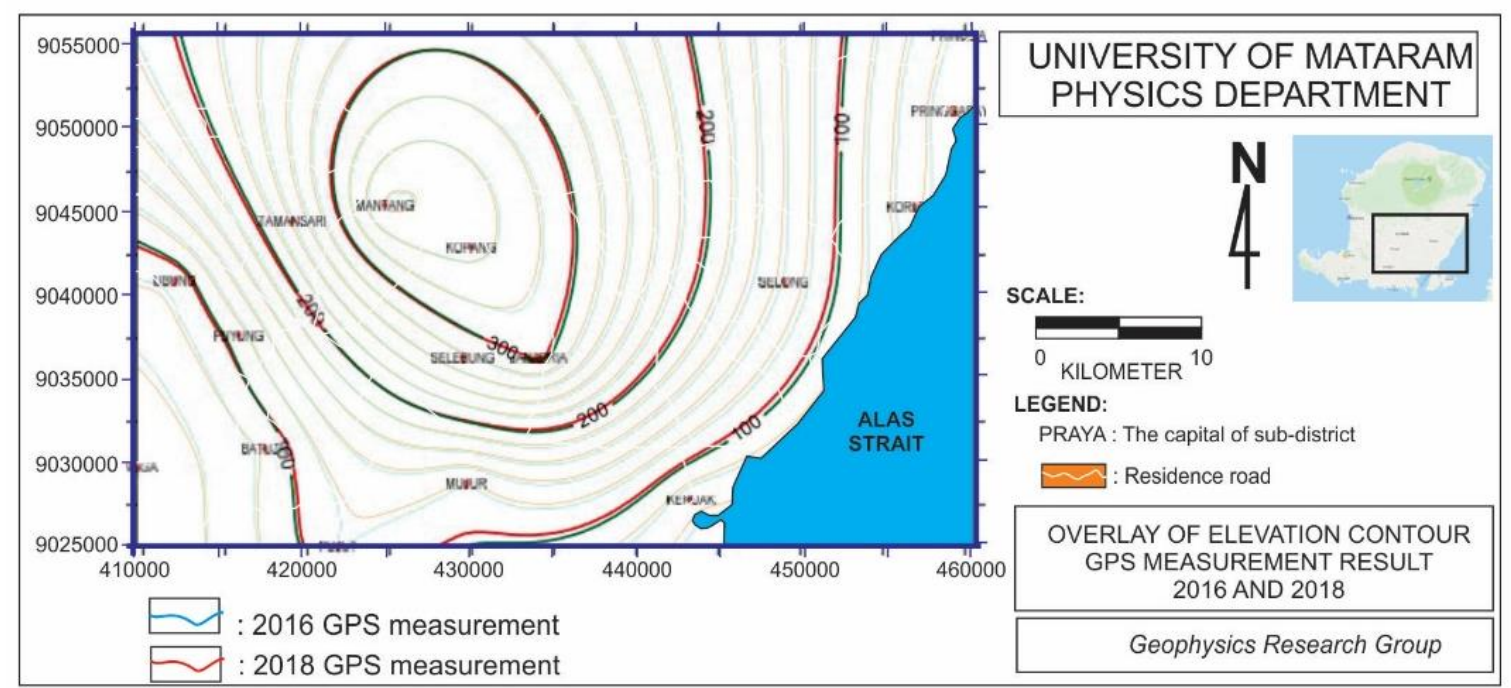

Figure 1. Overlay of contour lines from 2 times GPS measurements (2016 and 2018) [modified from 4]

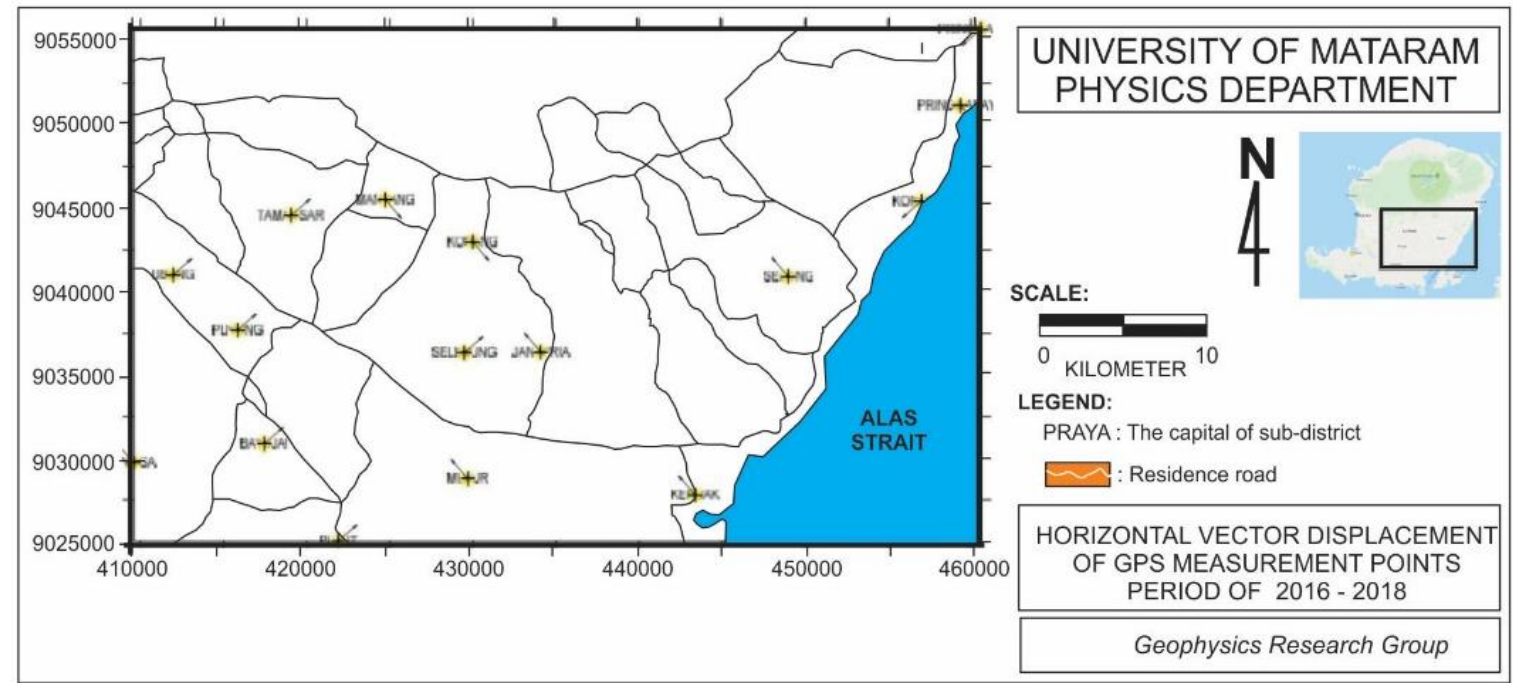

Figure 2. The direction of shifting GPS points for the period 2016 - 2018 [modified from 4]

\section{TRANSFORMATION OF WAY ANOMALY WEIGHT DATA INTO TIME TO BECOME DATA DEFORMATION}

Anomaly microgravity between measured time is a change in the value of measured gravity over a certain time interval [5] as shown in equation (1)

$$
\begin{aligned}
\Delta g(x, y, t, \Delta t) & =g_{o b s(2)}-g_{o b s(1)} \\
& =g\left(x, y, z, t_{2}\right)-g\left(x, y, z, t_{1}\right)
\end{aligned}
$$

These time-lapse microgravity anomalies are anomalies from various sources, anomalies due to sources on the surface / near-surface (shallow source) and due to sources in depth (deep source) [6], as shown in equation (2).

$$
\begin{aligned}
\left(g_{o b s(2)}-g_{o b s(1)}\right)= & G \int_{0-\infty-\infty}^{\infty} \int_{0}^{\infty} \frac{\Delta \rho(\alpha, \beta, \gamma, \Delta t)}{\left[(x-a)^{2}+(y-\beta)^{2}+(z-\gamma)^{2}\right]^{3 / 2}} d \alpha d \beta d \gamma \\
& +\left(c_{1}-c_{2} \rho\right)\left(h_{2}-h_{1}\right)
\end{aligned}
$$

where $g_{o b s(1)}$ and $g_{o b s(2)}$ are the gravity measurement values in the first and second measurements, $\mathrm{G}$ is the general constant of gravity, $\Delta \rho$ is the contrast density, $(\alpha, \beta, \gamma)$ is the coordinate of the anomalous object, $\Delta \mathrm{t}$ is the time interval between two measurements, $(\mathrm{x}, \mathrm{y}, \mathrm{z})$ are station coordinate (point) measurements, $c_{1}$ is the constant for free air correction $\left(=0.30876 \mathrm{~s}^{-2}\right), \mathrm{c}_{2}$ is the constant for Bouguer correction $\left(=0.04193 \mathrm{~cm} 3 . \mathrm{gr}^{-2} \mathrm{~s}^{-2}\right), \mathrm{h}_{1}$ and $\mathrm{h}_{2}$ are the gravity point elevation elevations in the first and second measurements. 
The first term of the right-hand segment is an anomaly of microgravity originating from subsurface dynamics, such as changes in mass or subsurface fluid dynamics. The second term is anomalous microgravity originating on the surface, especially vertical deformation which is biased in the form of subsidence or removal.

Gravity anomalies due to density changes in the horizontal direction can be written in equation (3) as:

$$
\Delta g(x, y, 0)=
$$

$G \Delta \rho \int_{h_{1}}^{h_{2}} \int_{-\infty}^{\infty} \int_{-\infty}^{\infty} \frac{S(\alpha, \beta, \gamma)}{\left[(x-\alpha)^{2}+(y-\beta)^{2}+\gamma^{2}\right]^{3 / 2}} d \alpha d \beta d \gamma$

To get the value of anomalies that occur on the surface, due to subsidence or removal, time-lapse microgravity anomalies must be separated into microgravity anomalies that are shallow sourced and deep sourced in $[7,8,9,10]$. One filter that can be used for this purpose is striping filter, developed by $[8,9]$.

If the anomaly measured on the surface is a superposition of anomalies originating near the surface and surface surface, the total anomaly can be stated as:

$$
g(x, y)=g_{d}(x, y)+g_{s}(x, y)
$$

where the $\mathrm{s}$ and $\mathrm{d}$ indices show shallow and deep. In the region of the wave number equation (3) and (4) can be written in the form of equations (5) and (6):

$$
\begin{aligned}
G(u, v, 0)= & \frac{8 \pi K}{k u v} \cdot \Delta \rho \cdot \sin \cdot\left(\frac{a u}{2}\right) \cdot \sin \left(\frac{b v}{2}\right) \\
& \cdot e^{-k h_{l}\left[1-e^{-k\left(h_{b}-h_{t}\right)}\right]}
\end{aligned}
$$

and

$$
G(u, v)=G_{s}(u, v)+G_{d}(u, v)
$$

where $\mathrm{u}$ and $\mathrm{v}$ are the coordinates of the wavenumber, $\mathrm{G}(u, v)$ is the result of the Fourier transform (TF) of $\mathrm{g}(\mathrm{x}, \mathrm{y}), \mathrm{G}_{\mathrm{s}}(\mathrm{u}, \mathrm{v})$ is the TF of $\mathrm{g}_{\mathrm{s}}(\mathrm{x}, \mathrm{y}), \mathrm{G}_{\mathrm{d}}(\mathrm{u}, \mathrm{v})$ is the TF of $g_{d}(x, y), t_{s}=h_{b s}-h_{t s}$ and $t_{d}=h_{b d}-h_{t d}$ respectively are the thickness of the prism from shallow and deep sources. Furthermore, equation (6) can be written in the form of anomalies of shallow and deep sources separately, as follows:

$$
\begin{gathered}
G_{s}(u, v)=\frac{8 \pi K}{k u v} \cdot \Delta \rho \cdot \sin \cdot\left(\frac{a u}{2}\right) \cdot \sin \left(\frac{b v}{2}\right) \\
\cdot e^{-k h_{t_{s}}\left[1-e^{-k\left(h_{s}-h_{t_{s}}\right)}\right]}
\end{gathered}
$$

and

$$
\begin{aligned}
G_{d}(u, v)= & \frac{8 \pi K}{k u v} \cdot \Delta \rho \cdot \sin \cdot\left(\frac{a u}{2}\right) \cdot \sin \left(\frac{b v}{2}\right) \\
& \cdot e^{-k h_{h_{d}}\left[1-e^{-k\left(h_{b_{d}}-h_{t_{d}}\right)}\right]}
\end{aligned}
$$

Equations (7) and (8) are the basic equations for designing filter striping and filter striping for a shallow source anomaly spectrum which can be expressed in equation (9)

$$
S(u, v)=\left(1+\frac{G_{d}(u, v)}{G_{s}(u, v)}\right)^{-1}
$$

Substitution of equations (7) and (8) into equation (9) results in:

$$
S(u, v)=\left(1+\alpha \beta(u, v) e^{-k \xi}\right)^{-1}
$$

where $\alpha=\frac{\Delta \rho_{d}}{\Delta \rho_{s}}, \beta=\frac{1-e^{-k t_{d}}}{1-e^{-k t_{s}}}$, and $\xi=h_{t_{d}}-h_{t_{s}}$

Equation (10) is a filter striping that is formally the same as the equation proposed by [8] and [9]. Where $\alpha$ is the ratio of shallow source and internal source density, $\beta$ thickness ratio ( $t$ ) and $\xi$ is the depth difference between the shallow source and deep source.

Based on the description above, this study is raining to analyze surface deformation (subsidence/uplifting) in Central Lombok and East Lombok districts by applying filter striping to separate time-lapse microgravity anomalies. To transform shallow source anomaly data into changes in elevation the free air equation is used, as follows

$$
\frac{\partial g}{\partial r}=\frac{\partial}{\partial r}\left(-G \frac{M}{r^{2}}\right)=2 G \frac{M}{r^{2}}=-\frac{2}{r} g
$$

By substituting the earth's radius of $6371 \mathrm{~km}$ and an average gravitational velocity value of $981,000 \mathrm{mgal}$, a change in gravity value due to changes in elevation of $-0.3086 \mathrm{mgal} \mathrm{m}^{-1}$ or $-3.086 \mu \mathrm{gal} . \mathrm{cm}^{-1}$. 


\section{EXPERIMENTAL METHOD}

The study sites are in Central Lombok and East Lombok Regencies with an area of approximately $(50 \times 30) \mathrm{km}^{2}$, as shown in Figure 3a. Gravity measurement points are 83 stations and measurements are carried out three times, in August 2016, April 2018, and June 2019. The equipment used is the Scintrex Autograv CG-5 gravimeter as shown in Figure 3b

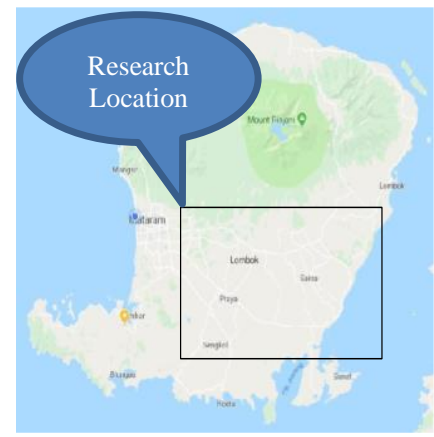

(a)

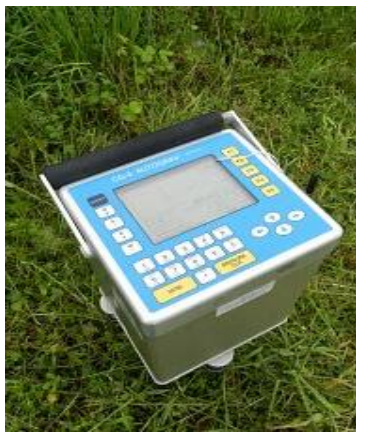

(b)
Figure 3. (a) Location of data collection [11]; (b) Scintrex Autograv CG-5 gravity gauge [12]

Stages of data processing to obtain information on the amount of deformation that occurs in the surface are presented in Figure 4.

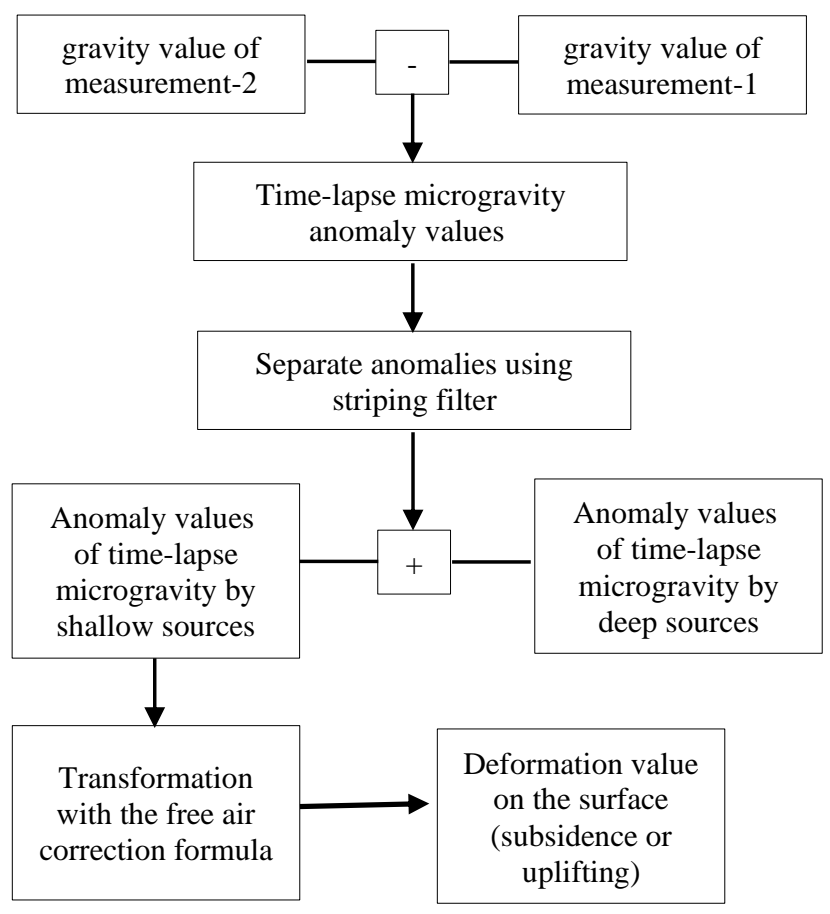

Figure 4. Stages of Data Processing of The Surface Deformation's Value.

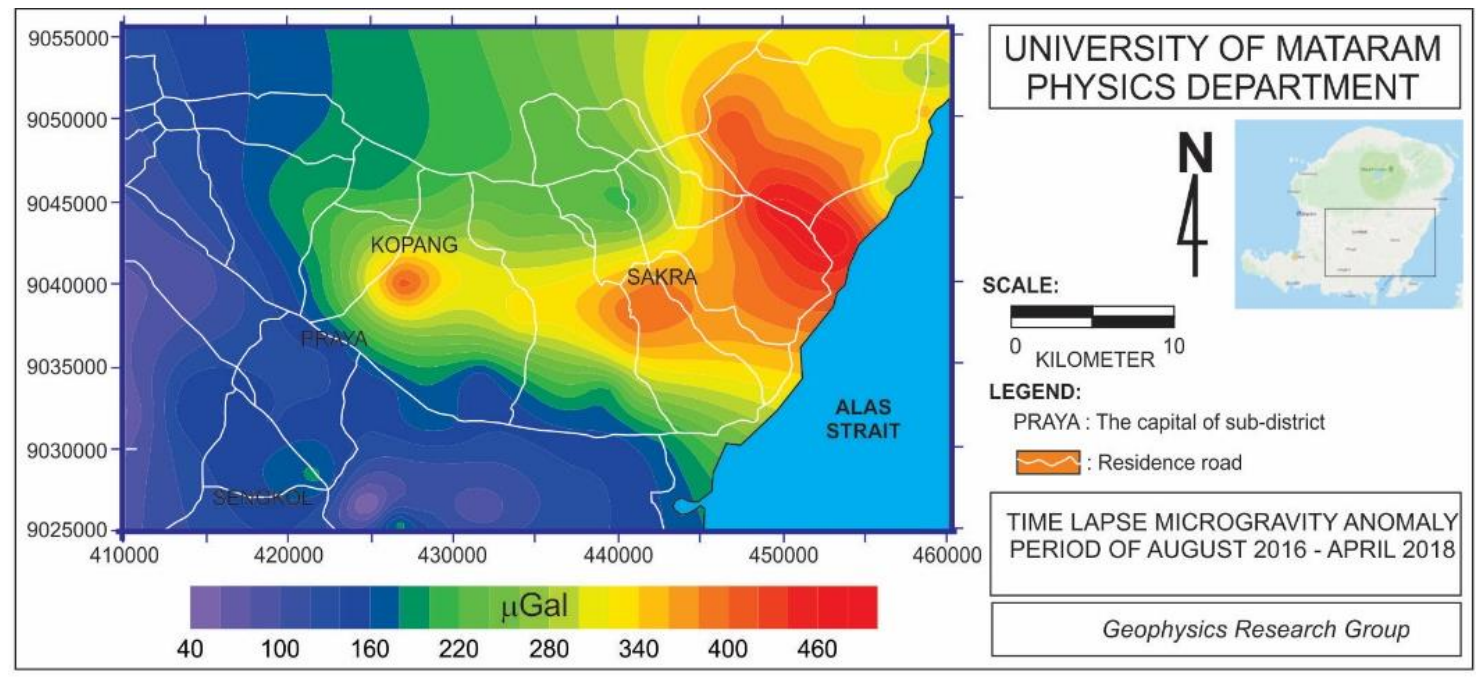

Figure 5. Anomalies of time-lapse microgravity periods 2016 - 2018 


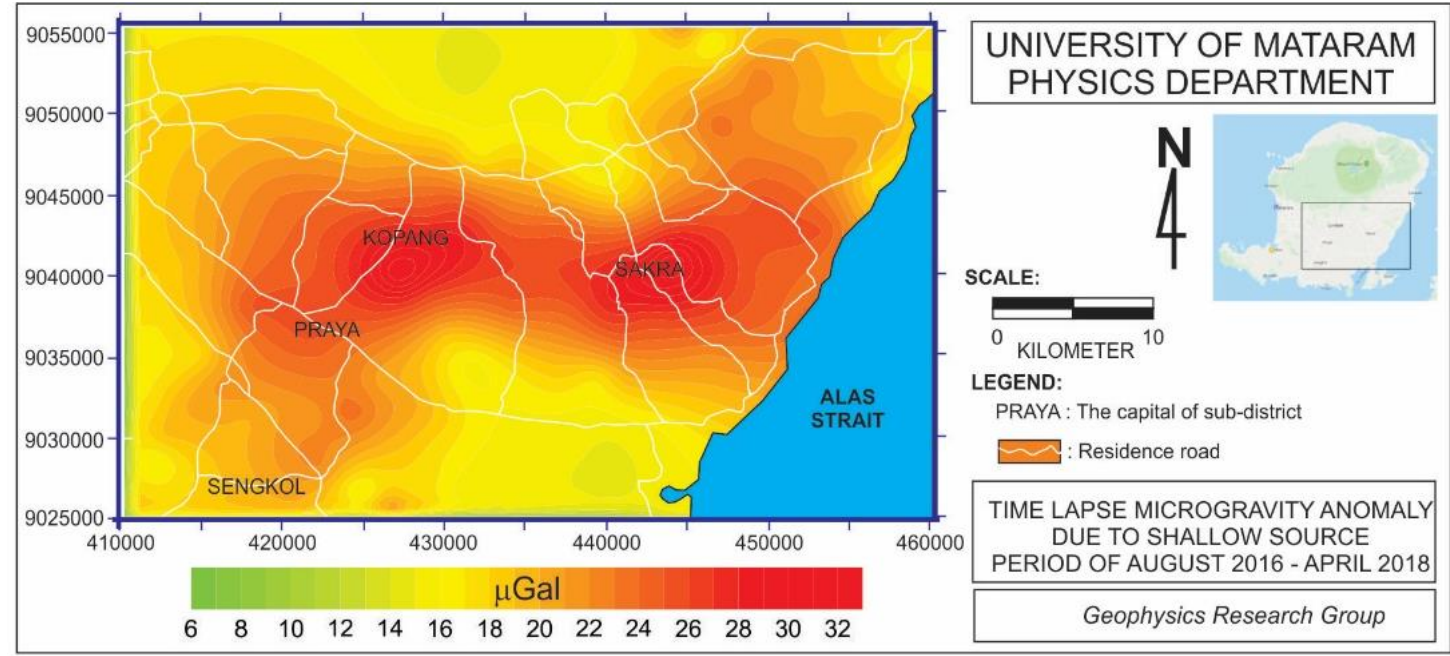

Figure 6. Anomalies of time-lapse microgravity due to shallow sources for the period 2016 - 2018

\section{RESULTS AND DISCUSSION}

Time-lapse microgravity anomaly the period 2016 to 2018 based on equation (1) is the difference between the results of measurements in 2018 and 2016. The value ranges from 40 to $480 \mu \mathrm{Gal}$, as shown in Figure 5, this shows that the results of measurements in 2018 are greater than the measurements of the year 2016. This positive change in value can be caused by land subsidence and the addition of mass below the surface.

The results of filtering by applying equation (10) obtained anomalies of time-lapse microgravity due to shallow source periods of 2016 to 2018, as shown in
Figure 6, as much as in the range (5 - 31) $\mu \mathrm{Gal}$. The filtering results, as well as time-lapse microgravity anomalies in this period, are also positive. This positive value indicates that the measuring point is closer to the center of the earth (the elevation has decreased)

In the period 2018 - 2019, the time-lapse microgravity anomaly measured in this period ranges from -900 to 0 mGall. Time-lapse microgravity anomalies at this period due to shallow sources are also negative, ranging from (-42 to -2$) \mu$ Gall. The result of anomaly filtering for anomaly due to shallow source period of 2018 to 2019 and period of 2016 to 2019 presented in figure 7 dan figure 8 .

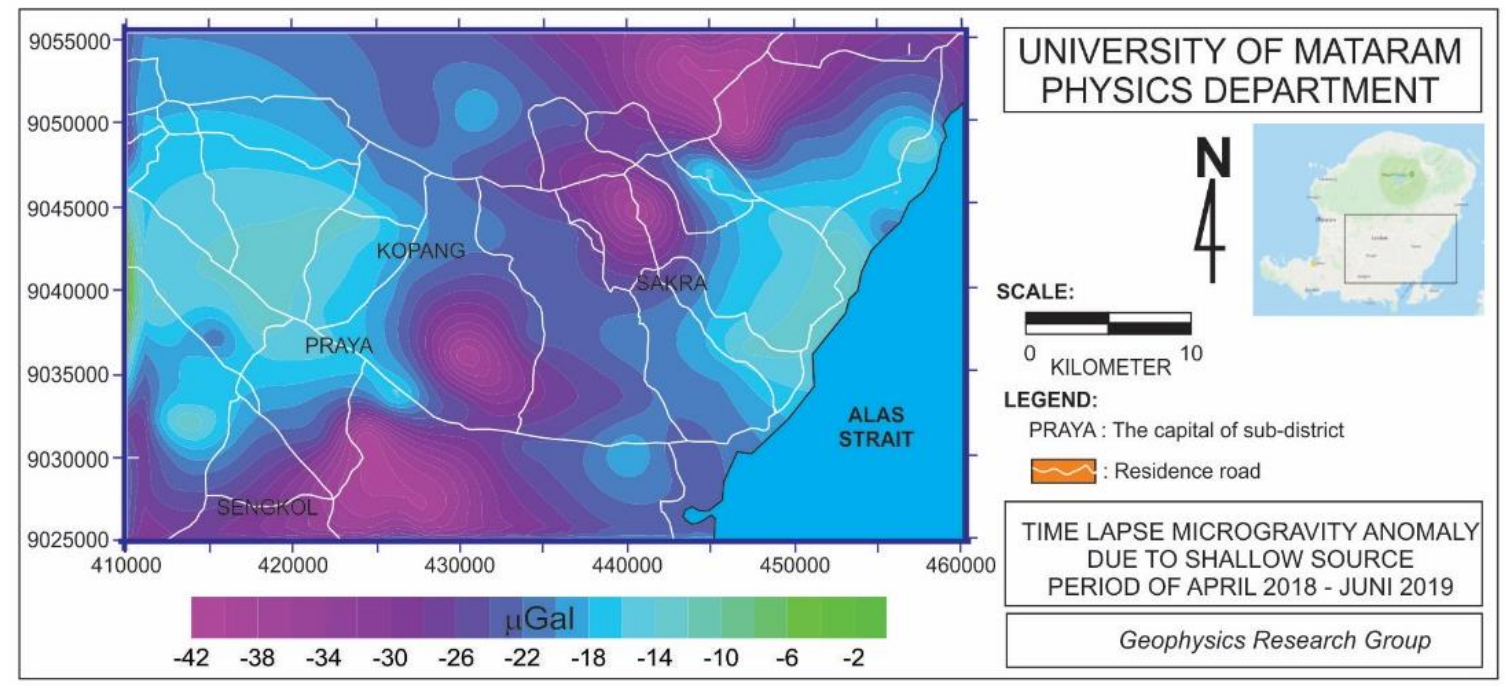

Figure 7. Anomalies of time-lapse microgravity due to shallow sources in the period 2018-2019 


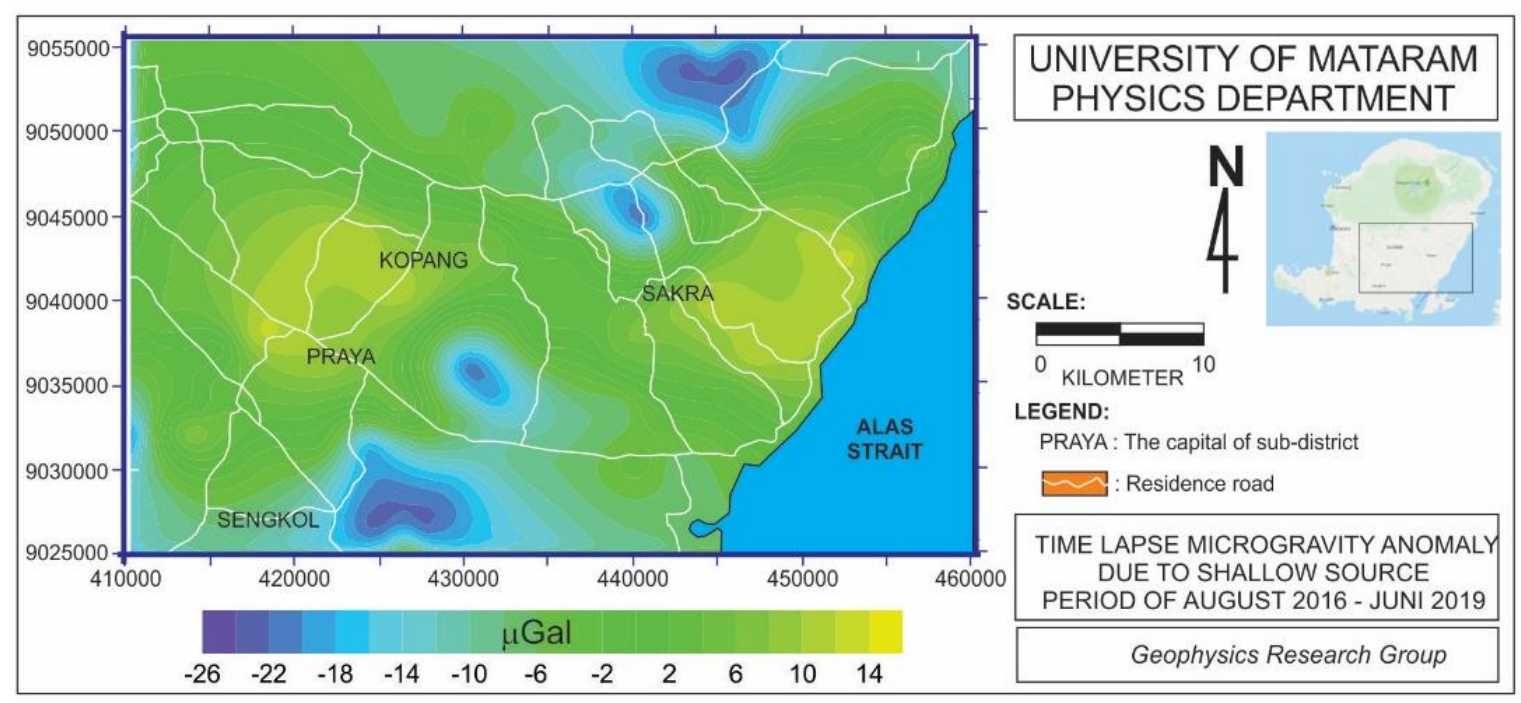

Figure 8 . The anomaly of time-lapse microgravity due to shallow sources for the period 2016-2019

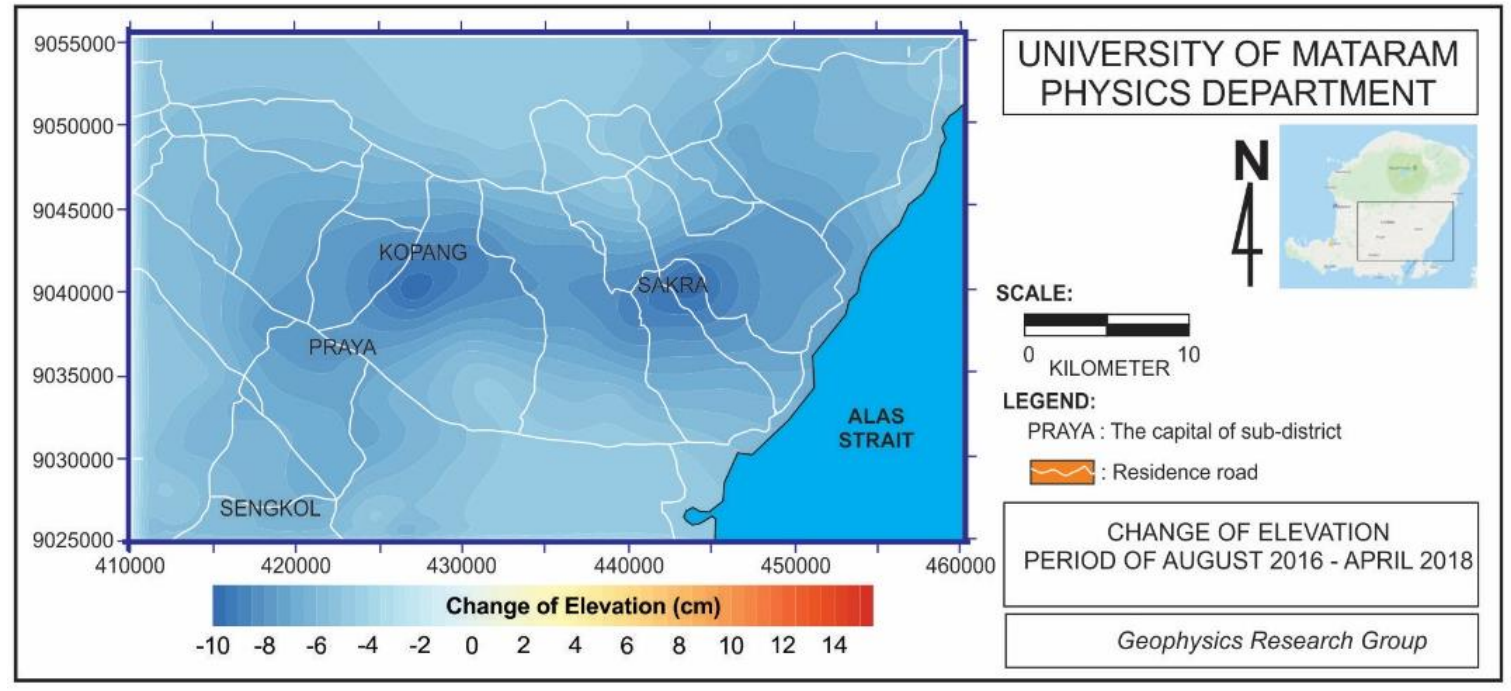

Figure 9. Changes of elevation for the period of 2016 to 2018

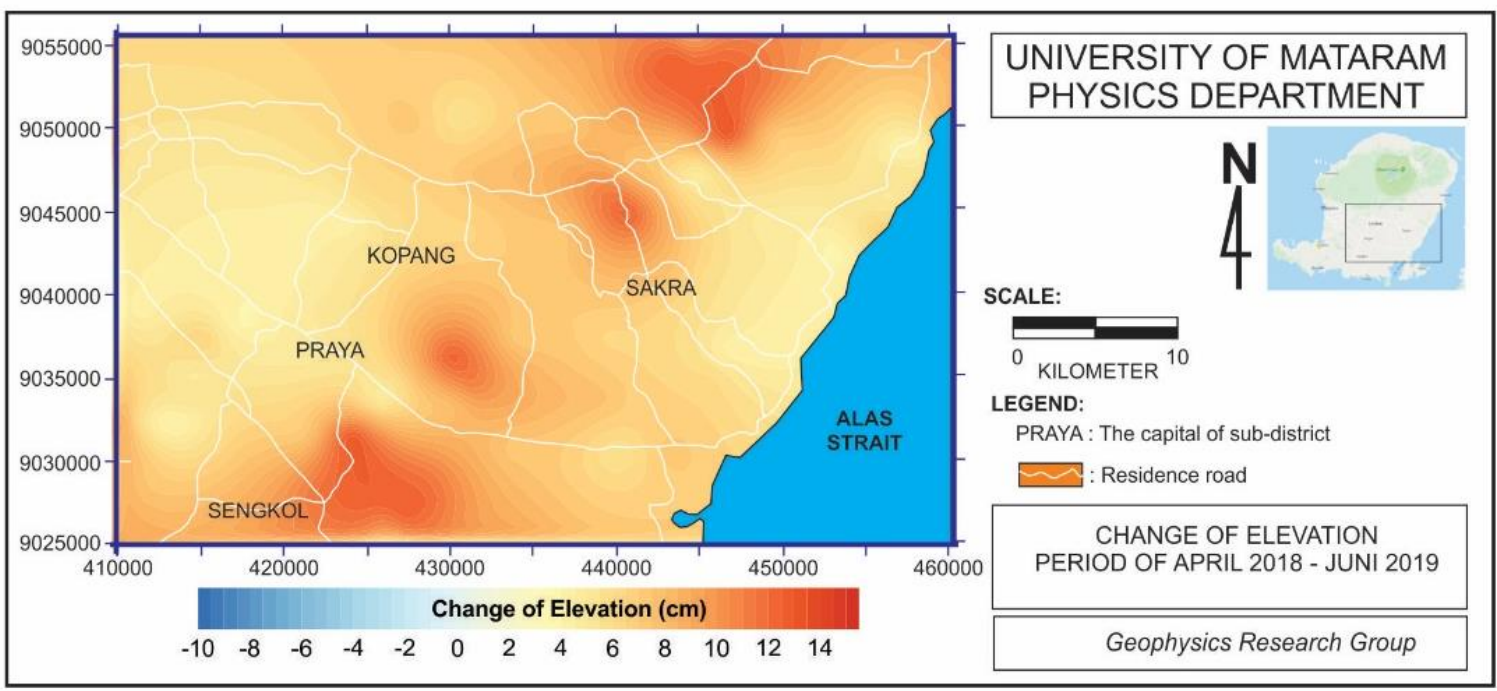

Figure 10. Changes in elevation from 2018 to 2019 


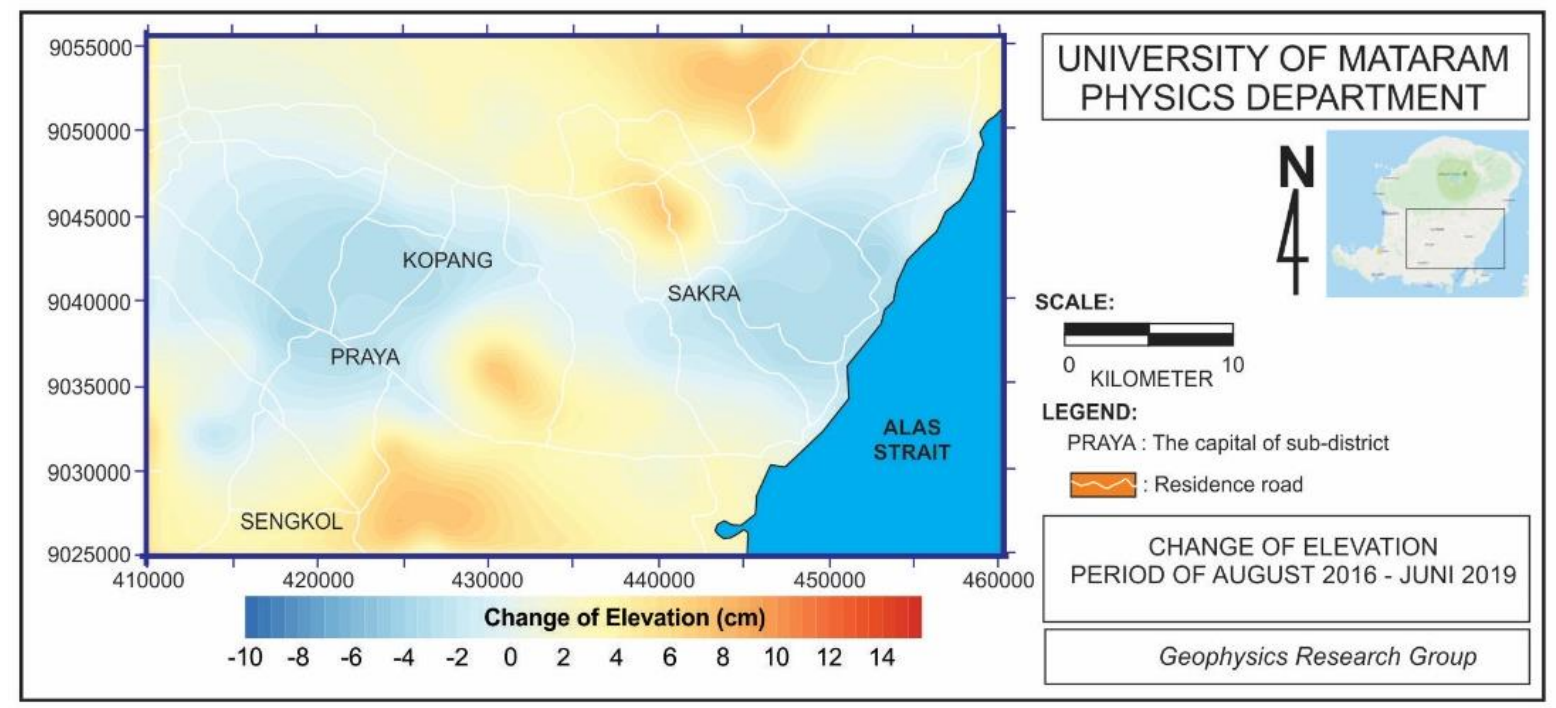

Figure 11. Changes in elevation for the period of 2016 to 2019

Using free air anomaly formula (equation 11) anomaly due to shallow source able to transform to change of elevation value. Result of that process for three periods, i.e. 2016 - 2018, 2018 - 2019, and 2016 - 2019, presented in figures 9, 10, and 11.

Changes in elevation in the period 2016 to 2019 is an accumulation of changes in the period $2016-2018$ and the period $2018-2019$. In the period 2016 - 2018 there was subsidence in all locations and due to the 2018 earthquake, the deformation became the opposite or land uplifting. The appointment that occurred in the period 2018 - 2019 has not been able to restore the elevation of the study area to the previous elevation, especially in areas with the highest subsidence (Praya, Kopang, and Sakra).

The anomaly values reversal event, which correlate with deformation that occurs, caused by earthquakes that occurred in July to August 2018. During that period there were at least 5 earthquakes with magnitudes greater than $5.5 \mathrm{SR}$, as presented in table 1 .

Table 1. Lombok quake parameters 2018 with magnitudes greater than 5.0 SR

\begin{tabular}{cccc}
\hline Dates & $\begin{array}{c}\text { Magnitudes } \\
(\mathrm{SR})\end{array}$ & Hypocenters & $\begin{array}{c}\text { Depth } \\
(\mathrm{km})\end{array}$ \\
\hline $29 / 07 / 2018$ & 6.4 & $116.508 \mathrm{E}, 8.324 \mathrm{~S}$ & 14.0 \\
$05 / 08 / 2018$ & 6.9 & $116.436 \mathrm{E}, 8.260 \mathrm{~S}$ & 31.0 \\
$09 / 08 / 2018$ & 5.9 & $116.208 \mathrm{E}, 8.394 \mathrm{~S}$ & 10.0 \\
$19 / 08 / 2018$ & 6.3 & $116.576 \mathrm{E}, 8.325 \mathrm{~S}$ & 7.9 \\
$19 / 08 / 2018$ & 6.9 & $116.626 \mathrm{E}, 8.324 \mathrm{~S}$ & 25.0 \\
$25 / 08 / 2018$ & 5.5 & $116.425 \mathrm{E}, 8.425 \mathrm{~S}$ & 9.2 \\
\hline
\end{tabular}

These earthquakes are a type of shallow earthquake due to the activity of the Flores Back Arc Thrust. The results of the analysis of the source mechanism show that this earthquake is still the same, an earthquake produced by rock deformation by fault mechanism. Due to the fault activity in the north of the Lombok Island, the Lombok Island experienced pressure to the south, on the other hand from the south there was pressure due to the activity of the Indo Australian Plate.

\section{CONCLUSION}

Based on the results of data processing and analysis, it can be concluded that in the period August 2016 to April 2018, all research areas experienced subsidence and during the period 2018 to 2019. all research areas occurred. The reversal of the deformation was caused by tectonic activity in the form of an earthquake that occurred in July to August 2018.

\section{ACKNOWLEDGMENT}

This research was funded by the Directorate of Research and Community Service of the Directorate General of Research and Technology Strengthening Ministry of Research, Technology and Higher Education with the Research Contract Number: 068/SP2H/LT/DPRM/2019. Thank you to the Chairman and staff of LPPM Mataram University, BMKG for their help and support during this research.

\section{REFERENCES}

[1] J.A. Katili, Review of Past and Present geotectonic concept of eastern Indonesia, Netherland Journal Sea. Res. 24(2/3), pp. $103-$ 129, 1989.

[2] Hamilton, Warren., 1979, Tectonics of the Indonesian region, USGS Professional Paper, 1078.

[3] Kertapati E., Aktivitas Gempabumi di Indonesia 
(Perspektif Regional pada Karakteristik Gempabumi Merusak), Pusat Survey Badan Geologi, Bandung, 2006.

[4] S. Minardi, T. Ardianto, A.T. Alaydrus, Deteksi Aktivitas Sesar Lombok Berdasarkan Data Anomali Gayaberat Mikro Antar Waktu Dan Geodetik, Proceedings of Seminar Kontribusi Fisika, (Dec. 5, 2018, Depertemen Fisika ITB, Bandung, Indonesia) 2019,

http://portal.fmipa.itb.ac.id/skf2018/kfz/procee dings/6.

[5] W.G.A Kadir, Prosiding PIT HAGI, 1999.

[6] D. Dahrin, Sarkowi, W.G.A. Kadir, S. Minardi, Penurunan Volume Airtanah Daerah Semarang berdasarkan Pemodelan 3D Gayaberat Antar
Waktu, Jurnal Geoaplika, 2 (1), pp. 11 - 17, 2007.

[7] S. Hammer, Geophysics, 28, pp. 369-378, 1963.

[8] L. Cordell, 55th Annual International Meeting, SEG, Expanded Abstracts, pp : 217-218, 1985.

[9] Aina, Adebayo, Geophysics, 59, pp. 488-490, 1994.

[10] Y. Li, and D.W. Oldenburg, Geophysics, 63, pp. 431-439, 1998.

[11] https://www.google.co.id/maps/@ 8.6071255,116.071663,10z?hl=en\&authuser $=0$, downloaded in December 16th, 2018 at 5:12 PM

[12] https://www.geomatrix.co.uk/landproducts/gravity/scintrex-cg5, downloaded in December 16th, 2018 at 5:20 PM 